\title{
A SIMPLIFIED METHOD FOR PURIFICATION OF AN ANTITUMOR ACIDIC GLYCOPROTEIN FROM STREPTOCOCCUS PYOGENES (Su STRAIN) BY IMMUNOADSORBENT CHROMATOGRAPHY
}

\author{
Junko Yoshida, Shozo Takamura and Shiro Suzuki \\ Department of Pharmacology, Kanazawa Medical University, \\ Ishikawa 920-02, Japan
}

(Received for publication September 16, 1988)

\begin{abstract}
A simplified method for purification of an antitumor acidic glycoprotein (SAGP) from Streptococcus pyogenes (Su strain) by immunoaffinity chromatography is described. A cellfree crude extract prepared from the cocci was applied to the anti-SAGP IgG coupled Sepharose column, and elution was conducted with an alkaline buffer. The material eluted was confirmed to be homogeneous and identical with SAGP as demonstrated by both relative mobility on the SDS-polyacrylamide gel column and the antigenicity on the double diffusion agar plate. The cell-growth inhibitory activity of SAGP prepared by the present method was almost the same as that of SAGP purified by the previous time-consuming method. Since this simplified method provides a higher yield of SAGP, it will be useful in further studies on the biological properties of SAGP.
\end{abstract}

We have purified previously streptococcal acid glycoprotein (SAGP) from the cell-free crude extract (CE) of Streptococcus pyogenes (Su strain) by a multi-step procedure"). SAGP is an acidic glycoprotein with the molecular weight of about 150,000 daltons and is composed of identical subunits of molecular weight 50,000 daltons. One of the carbohydrate moieties of SAGP was determined to be D-allose $(1.5 \% \mathrm{w} / \mathrm{w})$. In the antitumor experiments, SAGP prolonged the life span of mice bearing Ehrlich ascites carcinoma cells ${ }^{12}$ and inhibited the growth of some cell lines in culture, including transformed hamster embryonic lung cells (THEL) ${ }^{12}$, murine embryonic cells (BALB/3T3) ${ }^{2}$, murine leukemic L1210 cells (L1210), B16 melanoma and Meth A sarcoma cells (unpublished data). On the other hand, KANAOKA et al. ${ }^{3)}$ reported that SAGP, which was purified from $S$. pyogenes Su by a slightly modified procedure, inhibited the growth of several tumor cell lines in vitro and exhibited the antitumor effect on mice inoculated ip with Meth A sarcoma cells or mice implanted im with sarcoma 180 tumor cells. For more extensive studies on the biological properties of SAGP, it was necessary to obtain greater amounts of SAGP. The previous method for purification of SAGP was time-consuming and consisted of thermal treatment, streptomycin precipitation, ammonium sulfate fractionation, and some liquid chromatographic procedure ${ }^{1}$. In this paper, we describe a simplified and improved method for purification of SAGP by immunoaffinity chromatography.

\section{Materials and Methods}

\section{Preparation of Cell-free CE}

The cell-free CE was prepared as described previously1). Briefly, S. pyogenes (Su strain) cells grown in 30 liters of WOOD and Gunsalus broth ${ }^{4)}$ were collected by continuous centrifugation and washed with $0.01 \mathrm{M}$ Tris- $\mathrm{HCl}$ buffer, $\mathrm{pH} 7.5$ containing $0.01 \mathrm{M}$ magnesium acetate. After mechanical disruption of the cells in a Vibrogen cell mill (Edmund Bühler, Tübingen), a water-soluble fraction 
was obtained by centrifugation at $105,000 \times g$ for 2 hours and dialyzed against the $1 \mathrm{~mm}$ Tris-acetate buffer, $\mathrm{pH} 8.0$ containing $0.14 \mathrm{M} \mathrm{KCl}$ and $0.02 \%$ sodium azide (starting buffer). CE was subjected to immunoadsorbent chromatography as the starting material for the purification of SAGP.

\section{Antisera}

One mg of SAGP purified by the previous method ${ }^{1)}$ was emulsified in complete Freund's adjuvant. Rabbits were im inoculated at several sites of the body. One week later, the same dose of SAGP in complete FreUND's adjuvant was injected into the rabbits. For booster injection, $0.5 \mathrm{mg}$ of SAGP in FREUND's incomplete adjuvant was administered into the rabbits 4 weeks later. Rabbits were bled by cardiac puncture 4 weeks after the last injection, and the antisera were prepared by precipitation with $35 \%$ saturated ammonium sulfate, followed by purification on DE-52 cellulose column according to the method of LEVY and SOBER ${ }^{5)}$. The IgG fraction was concentrated to approximately $10 \mathrm{mg} / \mathrm{ml}$ with an UK-10 ultrafilter (Toyo Roshi, Tokyo, Japan).

\section{Preparation of Immunoadsorbent}

The anti-SAGP IgG was dialyzed against the coupling buffer; $0.5 \mathrm{M} \mathrm{NaCl}$ in $0.1 \mathrm{M} \mathrm{NaHCO}_{3}, \mathrm{pH}$ 8.3. Then IgG $(10 \mathrm{mg} / \mathrm{g}$ of Sepharose) was coupled to $\mathrm{CNBr}$-activated Sepharose 4B (Pharmacia, Uppsala, Sweden) according to manufacture's instructions. The immunoadsorbent was packed into a glass column $(1.6 \times 10 \mathrm{~cm})$, and equilibrated with the starting buffer.

\section{Assay of Cell-growth Inhibitory Activity}

Biological activity of obtained fractions was determined by the assay on cell-growth inhibition. THEL and L1210 cells were used as the target cell lines. THEL cells were routinely maintained in EAGLE's minimal essential medium supplemented with $12.5 \%$ of horse serum, $2.5 \%$ of fetal calf serum (FCS), and antibiotics (benzylpenicillin, $100 \mathrm{v} / \mathrm{ml}$; streptomycin, $100 \mu \mathrm{g} / \mathrm{ml}$ ), and $\mathrm{L} 1210$ cells in Roswell Park Memorial Institute Tissue Culture Medium 1640 supplemented with $10 \%$ FCS and antibiotics. Inhibition of cell-growth was assayed as described previously ${ }^{1)}$. Cells $\left(5 \times 10^{4} /\right.$ plate $)$ were inoculated into $5 \mathrm{ml}$ of the medium containing an appropriate concentration of sample to be tested and incubated at $37^{\circ} \mathrm{C}$ for 72 hours in a humidified $5 \% \mathrm{CO}_{2}$ atmosphere. The number of the cells was determined by a Coulter counter (model ZBI, Coulter Electronic, Inc.) and the growth rate was expressed as percentage of cell-number in the control plates.

\section{Other Methods}

Polyacrylamide gel disc electrophoresis in the presence of SDS was carried out as described previously ${ }^{1)}$. Ouchterlony double diffusion analysis ${ }^{6)}$ was carried out at room temperature. Protein concentration was determined by the method of LOWRY et al. ${ }^{7)}$ with bovine serum albumin as the standard.

\section{Results and Discussion}

Immunoaffinity chromatographic procedure was carried out at $4^{\circ} \mathrm{C} . \mathrm{CE}(10 \mathrm{mg}$ protein/ml) was applied onto the immunoadsorbent column with recycling for 16 hours at a flow rate of $20 \mathrm{ml} /$ hour. Unadsorbed materials were then washed out with at least 10 bed volumes of the starting buffer at a flow rate of $60 \mathrm{ml} /$ hour. The material adsorbed was eluted with freshly prepared lysine - $\mathrm{KOH}$ buffer, pH 11.0 containing $0.14 \mathrm{M} \mathrm{KCl}$. The eluate was collected in $2.5-\mathrm{ml}$ fractions and immediately neutralized with the same volume of $0.1 \mathrm{M}$ Tris-acetate buffer, $\mathrm{pH} 6.3$ containing $0.2 \mathrm{~m}$ glycine. A typical elution pattern is shown in Fig. 1. The eluted fractions containing protein, as determined by the optical density of the fractions at a wavelength of $280 \mathrm{~nm}$, were pooled and then concentrated using an UK-10 ultrafilter. The filtrate was dialyzed against DulBeCco's phosphate buffered solution, $\mathrm{pH}$ 7.3. The protein containing fraction thus obtained was subjected to physico-chemical and biological analyses. After elution, the column was washed thoroughly with 5 bed volumes of $0.1 \mathrm{M}$ acetate buffer, pH 4.0 containing $0.5 \mathrm{M} \mathrm{NaCl}$, followed by 5 bed volumes of $0.1 \mathrm{M}$ Tris- $\mathrm{HCl}$ buffer, 
Fig. 1. Single-step isolation of SAGP from a crude extract of the Streptococci on the immunoadsorbent affinity column.

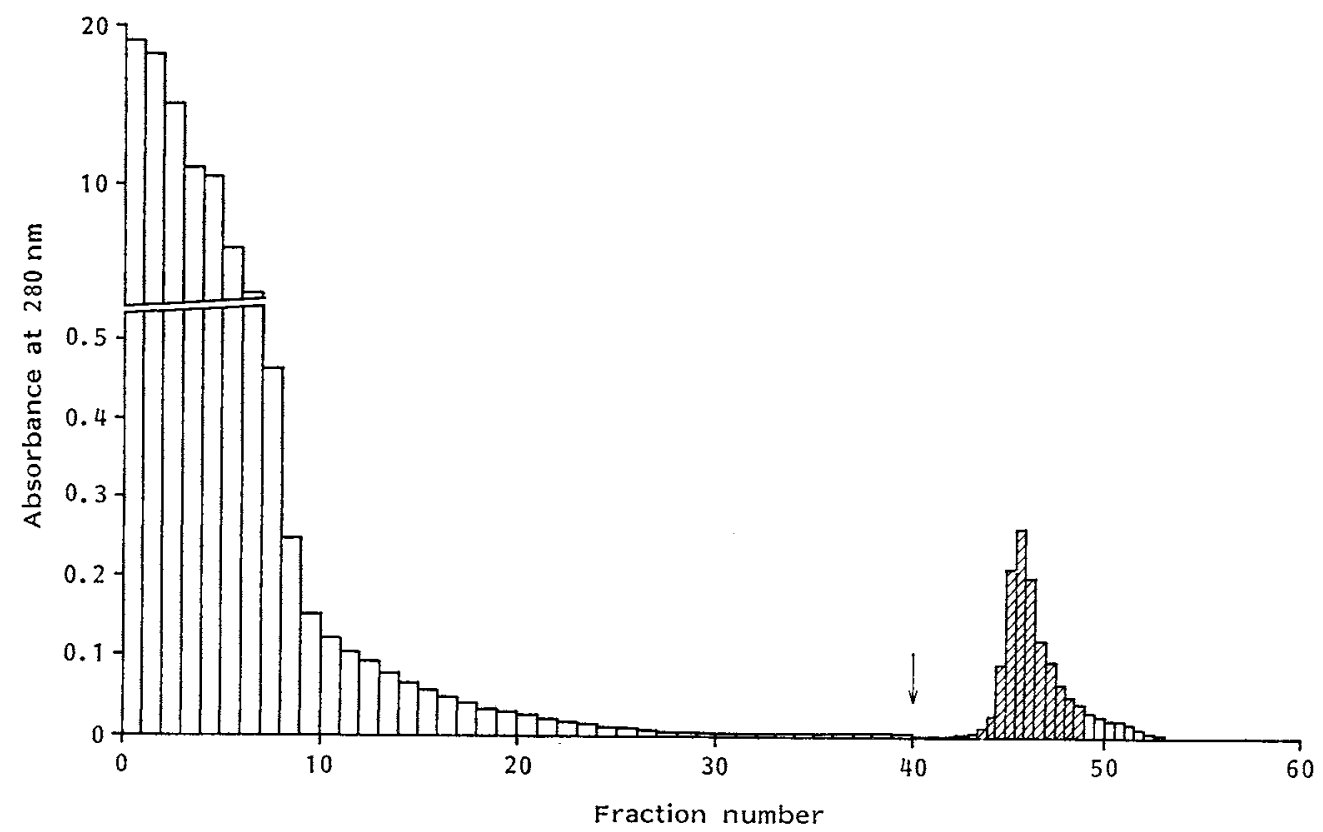

Arrow indicates change to the elution buffer. The hatched area containing SAGP was pooled, and concentrated.

pH 8.0 containing $0.5 \mathrm{M} \mathrm{NaCl}$, and re-equilibrated with the starting buffer. The affinity column could be repeatedly used at least 10 times without loss of the ability to adsorb SAGP.

$A$ portion of $\mathrm{CE}$, unadsorbed material and the eluted fraction from the column were reduced in the phosphate buffer containing $1 \% \mathrm{SDS}$ and $5 \% 2$-mercaptoethanol at $100^{\circ} \mathrm{C}$ for 3 minutes, and electrophoresed on $7.5 \%$ polyacrylamide gel column $(0.5 \times 6 \mathrm{~cm})$ in the presence of $0.1 \%$ SDS. At the same time, SAGP purified by the previous method (a multi-step procedure) was run as a control. The fraction eluted from the column was shown to have a relative mobility value corresponding to that of SAGP purified by a multi-step procedure (Fig. 2).

Ouchterlony double diffusion analysis showed a single precipitin line between the eluted fraction and anti-SAGP serum (Fig. 3). The precipitin line was fused with the line which was formed between SAGP purified by a multi-
Fig. 2. SDS-polyacrylamide gel electrophoresis of the fractions from the immunoaffinity column.

A: Starting material (CE), B: unadsorbed fraction passed through the column, $C$ : fraction eluted from the column, D: SAGP purified by a multi-step procedure.

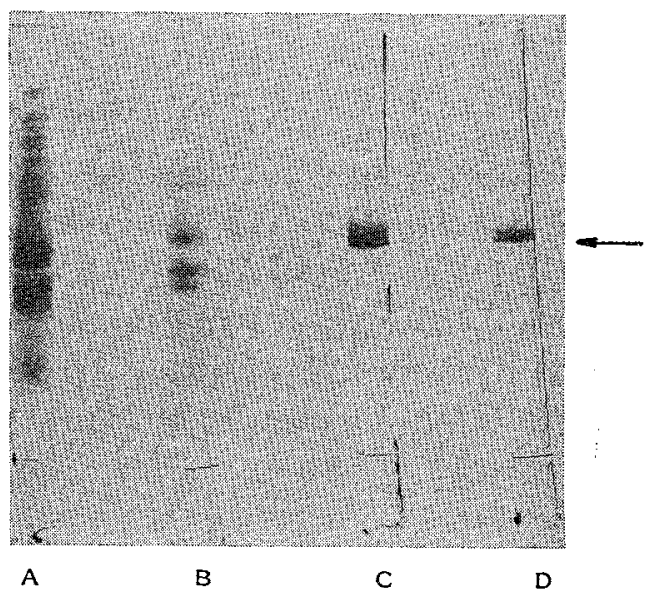

Gels were stained with Coomassie Brilliant Blue $\mathrm{R}-250$. Arrow indicates the 50,000 daltons region. 
step procedure and anti-SAGP serum. This demonstrates that the fraction eluted from the column was antigenically identical with SAGP. On the other hand, the unadsorbed material did not form any precipitin band with anti-SAGP serum, indicating that the SAGP in CE was largely adsorbed to the immunoadsorbent.

The growth-inhibitory effect of CE, unadsorbed material and eluted SAGP on L1210 and THEL cells is shown in Fig. 4. The $\mathrm{IC}_{50}$ value of the eluted SAGP was almost one-tenth that of CE, suggesting that the eluted SAGP was purified with a 10-fold increase in the cell-growth inhibitory activity by a single-step procedure using immunoadsorbent chromatography. The unadsorbed material exhibited no or low growth-inhibitory activity on L1210 and THEL cells. Table 1 shows the growth-inhibitory activity of SAGP eluted from the immunoaffinity column on L1210 and THEL cells in comparison with that of SAGP purified by a multi-step procedure. The cell-growth inhibitory activity of SAGP

Fig. 3. Agar gel precipitin pattern of fractions from the immunoadsorbent affinity column against antiSAGP rabbit serum.

A: $3 \mu 1$ of anti-SAGP rabbit serum, B: $3 \mu 1$ of CE ( $7 \mathrm{mg}$ protein $/ \mathrm{ml}), \mathrm{C}: 3 \mu \mathrm{l}$ of unadsorbed fraction $(2.6 \mathrm{mg}$ protein $/ \mathrm{ml}), \mathrm{D}: 3 \mu \mathrm{l}$ of fraction eluted from the column $(500 \mu \mathrm{g}$ protein $/ \mathrm{ml}), \mathrm{E}: 3 \mu \mathrm{l}$ of SAGP purified by a multi-step procedure $(400 \mu \mathrm{g}$ protein $/ \mathrm{ml}$ ).

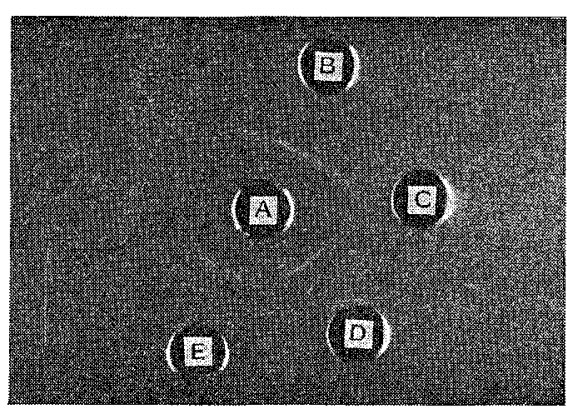

Fig. 4. The growth-inhibitory activity of the fractions from the immunoadsorbent affinity column on THEL (A) and L1210 (B) cells in culture.

Starting material (CE), $\square$ unadsorbed fraction, $\triangle$ fraction eluted from the column.

(A)

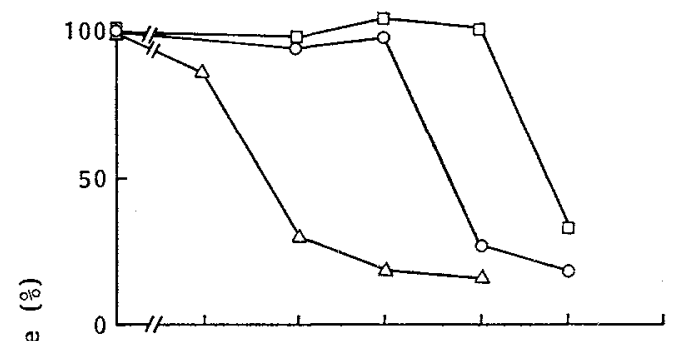

(B)

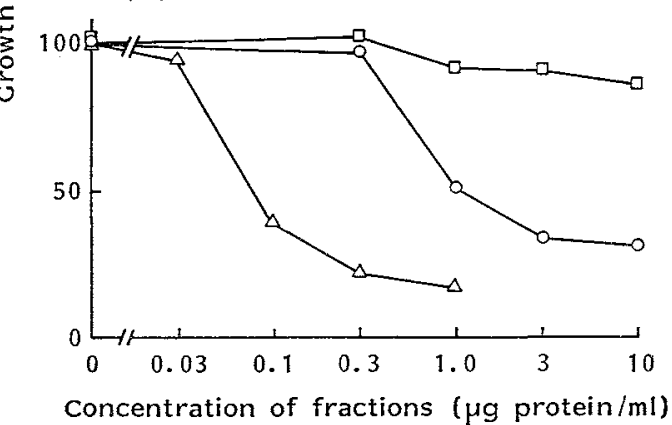

Table 1. Comparison of the cell-growth inhibitory effect of SAGP purified by the immunoadsorbent affinity chromatography with that of SAGP purified by a multi-step procedure.

\begin{tabular}{|c|c|c|c|c|c|}
\hline \multirow{3}{*}{$\begin{array}{c}\text { Target } \\
\text { cells }\end{array}$} & \multirow{3}{*}{ SAGP purified by } & \multicolumn{4}{|c|}{ Growth rate $(\%)$} \\
\hline & & \multicolumn{4}{|c|}{ Final concentration of SAGP ( $\mu \mathrm{g}$ protein $/ \mathrm{ml}$ ) } \\
\hline & & 0.03 & 0.1 & 0.3 & 1.0 \\
\hline \multirow[t]{2}{*}{ THEL } & $\begin{array}{l}\text { Immunoadsorbent } \\
\text { affinity chromatography }\end{array}$ & $91.0 \pm 5.1^{*}$ & $35.5 \pm 4.5$ & $22.0 \pm 4.9$ & $19.0 \pm 1.0$ \\
\hline & Multi-step procedure & $82.0 \pm 12.6$ & $28.5 \pm 2.9$ & $22.0 \pm 3.2$ & $17.5 \pm 3.6$ \\
\hline \multirow[t]{2}{*}{ L1210 } & $\begin{array}{l}\text { Immunoadsorbent } \\
\text { affinity chromatography }\end{array}$ & $91.0 \pm 9.2$ & $44.8 \pm 8.0$ & $24.5 \pm 2.2$ & $20.5 \pm 3.6$ \\
\hline & Multi-step procedure & $96.5 \pm 10.5$ & $40.5 \pm 1.5$ & $25.0 \pm 3.9$ & $20.3 \pm 1.9$ \\
\hline
\end{tabular}

* Mean \pm SE $(n=3)$. 
purified by each method was almost the same. In the preliminaly experiment, the antitumor effect of SAGP purified by immunoadsorbent chromatography was demonstrated in tumor-bearing mice. Namely, the mice were inoculated ip with Ehrlich ascites carcinoma cells on day 0. SAGP was injected ip into 3 mice at a dose of $500 \mu \mathrm{g} /$ mouse/day on day 1 to 4 . The 5 control mice received $0.9 \%(\mathrm{w} / \mathrm{v}) \mathrm{NaCl}$ solution alone. As a result, two of 3 mice administered SAGP were alive at day 60 , the termination of the experiment, whereas the control mice died in less than 24 days.

Thus, the SAGP bound to the immunoadsorbent was eluted in a pure form without loss of the biological activity. In immunoaffinity chromatography, some typical eluants; acids, bases and high concentrations of chaotropic ions or protein denaturants have been employed. We have tried to elute the bound material with bases ( $50 \mathrm{~mm}$ sodium bicarbonate $-0.3 \mathrm{M} \mathrm{NaCl}$ buffer, $\mathrm{pH} 11.0,50 \mathrm{~mm}$ $\mathrm{NH}_{4} \mathrm{OH}$ buffer, $\mathrm{pH} 10.0$ containing $20 \%$ glycerol), acids (0.1 м glycine- $\mathrm{HCl}$ buffer, $\left.\mathrm{pH} 3.0\right)$ and chaotropic ions ( $3.5 \mathrm{M} \mathrm{KI}, 1.0 \sim 2.5 \mathrm{M} \mathrm{NaI}, 3 \mathrm{M} \mathrm{MgCl}_{2}$ in the starting buffer) ${ }^{8)}$. SAGP eluted with those eluants had low activity in the cell-growth inhibitory effect. SAGP seems to be denatured by exposure to extreme conditions for a long time. The labile nature of SAGP might be due to partial dissociation of SAGP into the subunits. However, several observations indicate that the dissociation of the multisubunit proteins could be readily reversed by removing the denaturants or reactivating in an appropriate condition ${ }^{8}$. Therefore, eluants which minimize dissociation of SAGP should be chosen and also the material eluted should be returned to the native state immediately. Reproducible results were achieved using $5 \mathrm{~mm}$ lysine- $\mathrm{KOH}$ buffer, $\mathrm{pH} 11.0$ containing $0.14 \mathrm{M} \mathrm{KCl}$ as an eluant.

In terms of yield, the present method provided about $5 \mathrm{mg}$ of SAGP from $20 \mathrm{ml}$ of CE $(10 \mathrm{mg}$ protein $/ \mathrm{ml}$ ). The previous method yielded about $0.5 \mathrm{mg}$ of SAGP per $20 \mathrm{ml}$ of CE. Furthermore, the purification of SAGP by the present method takes only 3 days, whereas the previous method by a multi-step procedure takes at least 1 month. For larger preparations of SAGP, it would be convenient to repeat applications of $\mathrm{CE}$ to the same column and if possible, to prepare a larger column for bulk purification.

In conclusion, the immunoaffinity chromatographic procedure is a greatly improved method for purification of SAGP with higher yield in a shorter time. The new method will facilitate further research into the antitumor mechanisms of Streptococci ${ }^{10,11)}$ or streptococcal (Su strain) antitumor preparation; OK-432 $2^{12)}$.

\section{Acknowledgments}

This study was supported in part by the Science Research Promotion Fund from the Japan Private Promotion Foundation. We would like to thank Dr. T. DATE of the Department of Biochemistry of this University for valuable discussion. We are grateful to Miss Y. SHINZAWA for typing the manuscript.

\section{References}

1) Yoshida, J.; M. Yoshimura, S. Takamura \& S. Kobayashi: Purification and characterization of an antitumor principle from Streptococcus hemolyticus, Su strain. Jpn. J. Cancer Res. (Gann) 76: 213 223, 1985

2) Yoshida, J.; S. Takamura \& S. Suzuki: Cell growth-inhibitory action of SAGP, an antitumor glycoprotein from Streptococcus pyogenes (Su strain). Jpn. J. Pharmacol. 45: 143 147, 1987

3) Kanaoka, M.; Y. Fukrta, K. Taya, C. Kawanaka, T. Negoro \& H. Agur: Antitumor activity of streptococcal acid glycoprotein produced by Streptococcus pyogenes Su. Jpn. J. Cancer Res. (Gann) 78: $1409 \sim 1414,1987$

4) Wood, A. J. \& J. C. Gunsalus: The production of active resting cells of streptococci. J. Bacteriol. 44: 
$333 \sim 341,1942$

5) Levy, H. B. \& H. A. Sober: A simple chromatographic method for preparation of gamma globulin. Proc. Soc. Exp. Biol. Med. 103: 250 252, 1960

6) KeLETI, G. \& W. H. Lederer (Ed.): Ouchterlony gel diffusion. In Handbook of Micromethods for the Biological Sciences. pp. 130 133, Van Nostrand Reinhold Company, New York, 1974

7) Lowry, O. H.; N. J. Rosebrough, A. L. Farr \& R. J. Randall: Protein measurement with the Folin phenol reagent. J. Biol. Chem. 193: 265 275, 1951

8) Lowe, C.R.: Applications of affinity chromatography to the purification of regulatory macromolecules and complex biological structures. In Laboratory Techniques in Biochemistry and Molecular Biology. An Introduction to Affinity Chromatography. Ed., T. S. Work et al., pp. 466 479, North-Holland Publishing Company, Amsterdam, 1979

9) Friedman, F. K. \& S. BEYCHOK: Probes of subunit assembly and reconstitution pathways in multisubunit proteins. Annu. Rev. Biochem. 48: 217 250, 1979

10) Nauts, H. C.; W. E. Swift \& B. L. Coley: The treatment of malignant tumors by bacterial toxins as developed by the late William B. Coley, M. D., reviewed in the light of modern research. Cancer Res. 6: $205 \sim 216,1946$

11) Sног, S.: Isolation and fractionation of cell-free extract from streptolysin S-forming streptococci. Gann 67: $661 \sim 667,1976$

12) Oкамото, H.; S. Shoin \& S. Koshimura: Streptolysin S-forming and antitumour activities of Group A streptococci. In Bacterial Toxins and Cell Membranes. Eds., J. JeLJaszewicz \& T. WAdströM, pp. 259 289, Academic Press, London, 1978 